\title{
USE OF LINEAR PROGRAMMING PROBLEM IN SMALL SCALE PAPER INDUSTRIES: A CASE STUDY OF COST MINIMIZATION STRATEGY FOR MILLENNIAL INDUSTRIALISTS
}

\author{
Dr. Abhijit Pandit \\ Amity Business School \\ Amity University, Kolkata, West Bengal, India
}

\begin{abstract}
The main aim of the present research paper is to use linear programming problem in Small scale Industries for example paper, textiles, plastic and many more to help minimize the cost of manufacturing. There are the different models for solving the one dimensional, two dimensional, three dimensional and more models for stock cutting problem in the manufacturing industry. Linear programming (LP) is one of the simplest ways to perform optimization. It helps you solve some very complex optimization problems by making a few simplifying assumptions. As an analyst you are bound to come across applications and problems to be solved by Linear Programming.
\end{abstract}

Keywords - Operation research, linear programming, cutting stock, minimization

\section{INTRODUCTION}

Most of small and large paper manufacturing companies are linear programming based (Dantzig (1998)). Cutting stock problem is the length problem of making the material available at a given cost the cost of a specified number of sizes of material to be cut from the specified stock by the customer at a minimum cost (Tanir et al (2016)). This difficulty persists when there is only one approximate solution. This problem can be solved by linear programming (Chvatal et al (1983)). Linear programming is described to overcome the difficulty of formulation(Gilmore et al (1961)). The large numbers of variables involved usually computes and solve the problem by linear programming techniques. In this study the pattern oriented approach is adopted to construct the cutting stock model(De Carvalho(2002)), a cutting pattern algorithm (Wang (1983)) is developed and solve by Lingo software (Krishnaraj et al (2015)) has been used. Linear programming (LP) model is containing by several possible patterns (Ogunranti et al (2016)). In industries such as paper, plastic food wrap, and textiles, products are initially manufactured in large economically manufactured sizes (Stier (1985)). These sizes are cut into smaller, more usable sizes because the product is held by the consumer (Paine et al (2012)).

\section{PROPOSED AlgORITHM}

\section{A. Cutting paper Problem -}

Bharat paper industry produces a large number of papers. The price of raw materials is an important part of the purchase of paper sheets (Gao et al (2003)). Currently, sheet paper is purchased in three different size widths: 72 inches, 48 inches and 36 inches. In the manufacturing process, eight different widths of paper sheets are required (inches): 60, 56, 42, 38, 34, 24, 15 and 10. All uses need the equal quality and thickness of paper sheet (Machelen et al (2016)). A constant problem is cutting paper waste (Denen et al (2003)). For example, single way to cut a 72-inch width of paper is to move it to a 38-inch width and two 15-inch widths. After this, 4-inch trim waste will have to be removed. The linear foot prices of width of three different raw materials are $31.05 \mathrm{~kg}$ for width $36,41.4 \mathrm{~kg}$ for width 48 and $62.1 \mathrm{~kg}$ for "72" width. Ordinary arithmetic shows that the cost is three inches per inch. Widths for 36-inch, 48-inch and 72-inch widths respectively are Rs. is $69 \mathrm{~kg} / \mathrm{inch}$. The paper can be cut into any possible solution (Haessler (1992)). Potential cutting patterns are tabulated below to eliminate the width of the three raw materials. For example, pattern A1 is related to cutting a paper of 72 inches wide. There is 60 " wide with, one 10 " inches width and 2" left as trim waste. The sizes of different widths necessary in this plan period are:

\begin{tabular}{|c|c|c|c|c|c|c|c|c|}
\hline $\begin{array}{c}\text { Width(in } \\
\text { ches) }\end{array}$ & 60 & 56 & 42 & 38 & 34 & 24 & 15 & 10 \\
\hline $\begin{array}{c}\text { Number } \\
\text { of sheet } \\
\text { required }\end{array}$ & $\begin{array}{c}50 \\
0\end{array}$ & $\begin{array}{c}40 \\
0\end{array}$ & $\begin{array}{c}30 \\
0\end{array}$ & $\begin{array}{c}45 \\
0\end{array}$ & $\begin{array}{c}35 \\
0\end{array}$ & $\begin{array}{c}10 \\
0\end{array}$ & $\begin{array}{c}80 \\
0\end{array}$ & $\begin{array}{c}10 \\
0\end{array}$ \\
\hline
\end{tabular}

The raw material achievements during this scheduling period are $150 \mathrm{~kg}$ of $72 \mathrm{inch}$ paper and $100 \mathrm{~kg}$ each of 48 inch and 36 
Published Online July 2020 in IJEAST (http://www.ijeast.com)

inch width. How many feet of each pattern should be cut to reduce costs while meeting different width requirements?

\section{B. Total formulation of the problem -}

Representations of A1, A2,.., E4 Show the number of widths to cut the equivalent pattern in the following table:

\begin{tabular}{|c|c|c|c|c|c|c|c|c|c|}
\hline \multicolumn{10}{|c|}{$\begin{array}{c}\text { Raw Materials Cutting Patterns and Number of cuts required } \\
\text { width }\end{array}$} \\
\hline $\begin{array}{l}\text { Pattern } \\
\text { (inches) }\end{array}$ & 60 & 56 & 42 & 38 & 34 & 24 & 15 & 10 & Waste \\
\hline situation & \multicolumn{9}{|c|}{ 72" width Raw Material } \\
\hline AMT1 & 1 & 0 & 0 & 0 & 0 & 0 & 0 & 1 & 2 \\
\hline АMT2 & 0 & 1 & 0 & 0 & 0 & 0 & 1 & 0 & 1 \\
\hline AMT3 & 0 & 1 & 0 & 0 & 0 & 0 & 0 & 0 & 6 \\
\hline AMT4 & 0 & 0 & 1 & 0 & 0 & 1 & 0 & 0 & 6 \\
\hline AMT5 & 0 & 0 & 1 & 0 & 0 & 0 & 2 & 0 & 0 \\
\hline AMT6 & 0 & 0 & 1 & 0 & 0 & 0 & 1 & 0 & 5 \\
\hline AMT7 & 0 & 0 & 1 & 0 & 0 & 0 & 0 & 0 & 0 \\
\hline AMT8 & 0 & 0 & 0 & 1 & 1 & 0 & 0 & 0 & 0 \\
\hline АMT9 & 0 & 0 & 0 & 1 & 0 & 1 & 0 & 0 & 0 \\
\hline AMT10 & 0 & 0 & 0 & 1 & 0 & 0 & 2 & 0 & 4 \\
\hline AMT11 & 0 & 0 & 0 & 1 & 0 & 0 & 1 & 0 & 9 \\
\hline AMT12 & 0 & 0 & 0 & 1 & 0 & 0 & 0 & 0 & 4 \\
\hline AMT13 & 0 & 0 & 0 & 0 & 2 & 0 & 0 & 0 & 4 \\
\hline AMT14 & 0 & 0 & 0 & 0 & 1 & 1 & 0 & 0 & 4 \\
\hline AMT15 & 0 & 0 & 0 & 0 & 1 & 0 & 2 & 0 & 8 \\
\hline AMT16 & 0 & 0 & 0 & 0 & 1 & 0 & 1 & 0 & 3 \\
\hline AMT17 & 0 & 0 & 0 & 0 & 1 & 0 & 0 & 0 & 8 \\
\hline AMT18 & 0 & 0 & 0 & 0 & 0 & 3 & 0 & 0 & 0 \\
\hline AMT19 & 0 & 0 & 0 & 0 & 0 & 2 & 1 & 0 & 9 \\
\hline AMT20 & 0 & 0 & 0 & 0 & 0 & 2 & 0 & 0 & 4 \\
\hline
\end{tabular}

\begin{tabular}{|c|c|c|c|c|c|c|c|c|c|}
\hline AMT21 & 0 & 0 & 0 & 0 & 0 & 1 & 3 & 0 & 3 \\
\hline AMT22 & 0 & 0 & 0 & 0 & 0 & 1 & 2 & 0 & 8 \\
\hline AMT23 & 0 & 0 & 0 & 0 & 0 & 1 & 1 & 0 & 3 \\
\hline АMT24 & 0 & 0 & 0 & 0 & 0 & 1 & 0 & 0 & 8 \\
\hline AMT25 & 0 & 0 & 0 & 0 & 0 & 0 & 4 & 0 & 2 \\
\hline AMT26 & 0 & 0 & 0 & 0 & 0 & 0 & 3 & 0 & 7 \\
\hline AMT27 & 0 & 0 & 0 & 0 & 0 & 0 & 2 & 0 & 2 \\
\hline АMT28 & 0 & 0 & 0 & 0 & 0 & 0 & 1 & 0 & 7 \\
\hline AMT29 & 0 & 0 & 0 & 0 & 0 & 0 & 0 & 0 & 2 \\
\hline situation & \multicolumn{9}{|c|}{ 48" width Raw Material } \\
\hline АMT30 & 0 & 0 & 1 & 0 & 0 & 0 & 0 & 1 & 6 \\
\hline AMT31 & 0 & 0 & 0 & 1 & 0 & 0 & 1 & 1 & 0 \\
\hline АMT32 & 0 & 0 & 0 & 0 & 1 & 0 & 0 & 1 & 4 \\
\hline AMT33 & 0 & 0 & 0 & 0 & 0 & 2 & 0 & 0 & 0 \\
\hline АMT34 & 0 & 0 & 0 & 0 & 0 & 1 & 1 & 0 & 9 \\
\hline AMT35 & 0 & 0 & 0 & 0 & 0 & 1 & 0 & 2 & 4 \\
\hline АMT36 & 0 & 0 & 0 & 0 & 0 & 0 & 3 & 0 & 3 \\
\hline AMT37 & 0 & 0 & 0 & 0 & 0 & 0 & 2 & 1 & 8 \\
\hline AMT38 & 0 & 0 & 0 & 0 & 0 & 0 & 1 & 3 & 3 \\
\hline AMT39 & 0 & 0 & 0 & 0 & 0 & 0 & 0 & 4 & 8 \\
\hline situation & \multicolumn{9}{|c|}{ 48" width Raw Material } \\
\hline AMT40 & 0 & 0 & 0 & 0 & 1 & 0 & 0 & 0 & 2 \\
\hline AMT41 & 0 & 0 & 0 & 0 & 0 & 1 & 0 & 1 & 2 \\
\hline AMT42 & 0 & 0 & 0 & 0 & 0 & 0 & 2 & 0 & 6 \\
\hline AMT43 & 0 & 0 & 0 & 0 & 0 & 0 & 1 & 2 & 1 \\
\hline AMT44 & 0 & 0 & 0 & 0 & 0 & 0 & 0 & 3 & 6 \\
\hline
\end{tabular}

For purposes, it is useful to define additionally:

$\mathrm{T} 1=$ width cut of $72 "$ patterns,

$\mathrm{T} 2=$ width cut of 48 "patterns, 
$\mathrm{T} 3=$ width cut of $36^{\prime \prime}$ patterns,

$\mathrm{W} 1=$ inch of width waste from $72 "$ patterns,

$\mathrm{W} 2=$ inch of width waste from $48^{\prime \prime}$ patterns,

$\mathrm{W} 3$ = inch of width waste from 36 " patterns,

$\mathrm{X} 1=$ number of excess width cut of the 60 "width,

$\mathrm{X} 2=$ number of excess width cut of the 56 " width,

$\mathrm{X} 8=$ number of excess width cut of the 10 " width.

Minimize the total inch waste cost.

For example: $\mathrm{MIN}=0.8625 \mathrm{~W} 1+0.8625 \mathrm{~W} 2+0.86 \mathrm{~W} 3$;

This is especially possible when the cost per square inch is not the same for all raw material widths. A more reasonable objective is to reduce the total cost. i.e.

$\mathrm{MIN}=0.621 * \mathrm{~T} 1+0.414 * \mathrm{~T} 2+0.3105 * \mathrm{~T} 3$;

\section{EXPERIMENT AND RESULT}

MODEL:

SETS:

! Each raw material of the paper has a raw material width, the total is used,

Waste Total, Cost Per Unit, Waste Cost, and Supplies Available;

RM: RWDTH,T, W, C, WCOST, S;

! Each Finished good has a Width, units Required. eXtra produced;

FG: FWDTH, REQ, X;

PATTERN: USERM, WASTE, AMT;

PXF( PATTERN, FG): NUM;

ENDSETS

DATA:

! The raw material widths;

RM = R72 R48 R36;

RWDTH= 7248 36;

$\mathrm{C}=.621 .414 .3105$;

$\mathrm{WCOST}=.8625 .8625 .86$;

$\mathrm{S}=160010000$ 10000;

! The finished good widths;

$\mathrm{FG}=$ F60 F56 F42 F38 F34 F24 F15 F10,

FWDTH= 6056423834241510 ;

$\mathrm{REQ}=\begin{array}{llllllll}500 & 400 & 300 & 450 & 350 & 100 & 800 & 1000\end{array}$;

! Index of R.M. that each pattern uses;
USERM = 1111111111

1111111111

111111111

2222222222

33333 ;

! How many of each F.G. are in each R.M. pattern;

$\mathrm{NUM}=100000001$

01000010

01000001

00100100

00100020

00100011

00100003

00011000

00010101

00010020

00010011

00010003

00002000

00001101

00001020

00001012

00001003

00000300

00000210

00000202

00000130

00000121

00000113 
00000104

00000041

00000032

00000024

00000015

00000007

00100000

00010001

00001001

00000200

00000110

00000102

00000030

00000021

00000013

00000004

00001000

00000101

00000020

00000012

00000003 ;

\section{ENDDATA}

! Minimize cost of raw material used;

MIN = TCOST;

$\mathrm{TCOST}=@ \operatorname{SUM}(\mathrm{RM}(\mathrm{I}): \mathrm{C}(\mathrm{I}) * \mathrm{~T}(\mathrm{I}))$;

! Compute total cost of waste;

TOTWASTE = @SUM( RM(I): WCOST(I)*W(I) ); END

\section{CONCLUSION}

If we reduce the cost of paper waste, and then we will get a different solution if we reduce the total cost of raw materials (Clelland et al(2000)). The two different solutions obtained under two different objectives are compared in the following table:

\begin{tabular}{|l|l|}
\hline Patterns & $\begin{array}{c}\text { Minimize total } \\
\text { paper cost }\end{array}$ \\
\hline AMT1 & 500 \\
\hline AMT2 & 400 \\
\hline AMT5 & 171.4286 \\
\hline AMT7 & 128.571 \\
\hline AMT8 & 350 \\
\hline AMT25 & 14.28571 \\
\hline AMT31 & 100.0000 \\
\hline AMT33 & 50.00000 \\
\hline
\end{tabular}

Total waste 1232.143

Total paper cost 77521.93

T1 1564.286

T2 150.0000

T3 0

\section{REFERENCE}

[1] Chvatal, V., \& Chvatal, V. (1983). Linear programming. Macmillan

[2] Clelland, I. J., Dean, T. J., \& Douglas, T. J. (2000). Stepping towards sustainable business: An evaluation of waste minimization practices in US manufacturing. Interfaces, 30(3), (Pg 107-124)

[3] Dantzig, G. B. (1998). Linear programming and extensions (Vol. 48). Princeton university press

[4] De Carvalho, J. V. (2002). LP models for bin packing and cutting stock problems. European Journal of Operational Research, 141(2), (Pg 253-273)

[5] Denen, D. J., Yardley, C. D., Broehl, J. M., Hayes, R. J., Knittle, J. J., Linstedt, B. K., ... \& Moody, J. R. (2003). U.S. Patent No. 6,592,067. Washington, DC: U.S. Patent and Trademark Office.

[6] Gao, Z., \& Tang, L. (2003). A multi-objective model for purchasing of bulk raw materials of a large-scale integrated steel plant. International Journal of Production Economics, 83(3), (Pg 325-334). 
[7] Gilmore PC, Gomory RE(1961). A Linear Programming Approach to the Cutting-Stock Problem. Oper Res.;9(Pg 849-859).

[8] Haessler, R. W. (1992). One-dimensional cutting stock problems and solution procedures. Mathematical and computer modelling, 16(1), (Pg 1-8).

[9] Krishnaraj, C., Jayakumar, A. A., \& Shri, S. D. (2015). Solving Supply Chain Network Optimization Models Using LINGO. International Journal of Applied Engineering Research, 10(19), (Pg 14715-14718).

[10] Ogunranti GA, Oluleye AE(2016). Minimizing waste (off-cuts) using cutting stock model: The case of one dimensional cutting stock problem in wood working industry. J Ind Eng Manag. 9(Pg 834-59).

[11] Paine, F. A., \& Paine, H. Y. (2012). A handbook of food packaging. Springer Science \& Business Media.

[12] Stier, J. C. (1985). Implications of factor substitution, economies of scale, and technological change for the cost of production in the United States pulp and paper industry. Forest science, 31(4), (Pg 803-812).

[13] Tanir D, Ugurlu O, Guler A, Nuriyev U(2016). Onedimensional Cutting Stock Problem with Divisible Items.

[14] Van Mechelen, J. L. M., Maas, D. J. H. C., \& Merbold, H. (2016, September). Paper sheet parameter determination using terahertz spectroscopy. In 2016 41st International Conference on Infrared, Millimeter, and Terahertz waves (IRMMW-THz) (Pg. 1-2). IEEE.

[15] Wang, P. Y. (1983). Two algorithms for constrained twodimensional cutting stock problems. Operations research, 31(3), (Pg. 573-586). 